PROOFS: Please cite as Holden, Livia (forthcoming) Cultural Expertise and Law: An Historical Overview, Law and History Review, Cambridge.

\title{
Cultural Expertise and Law: An Historical Overview
}

\section{LIVIA HOLDEN}

Livia Holden is Senior Research Fellow at the University of Oxford, and Full Professor at the University of Padua

livia.holden@csls.ox.ac.uk; livia.holden@unipd.it $>$. She thanks Marius Holden for his meaningful advice and the LHR editorial team for their careful and accurate reading. This article is a primary output of the project titled "Cultural Expertise in Europe: What is it useful for?" (EURO-EXPERT) funded by the European Research Council (ERC) under H2020-EU.1.1. programme (ERC grant agreement no. 681814), Principal Investigator: Livia Holden. 
PROOFS: Please cite as Holden, Livia (forthcoming) Cultural Expertise and Law: An Historical Overview, Law and History Review, Cambridge.

The social sciences have long avoided engaging in any systematic analysis of the use of anthropological knowledge for dispute resolution, lawmaking, and governance. In order to fill this gap, cultural expertise was defined in 2009 as the special knowledge that enables sociolegal scholars, experts in non-European laws and cultures, or, more generally speaking, cultural mediators - the so-called cultural brokers - to locate and describe relevant facts in light of the particular background of the claimants and litigants and for the use of the court. ${ }^{1}$ Although the definition of cultural expertise is new, its existence is not. This article adopts a historical perspective to understand why sociolegal studies have not yet developed a conceptualization that encompasses the variety of the types of engagement of social scientists, and anthropologists in particular, with conflict resolution, lawmaking, and policy making.

This article explores the connection between law and culture in the history of anthropology of law since social evolutionism, and focuses in particular on the legal pluralism approach because of its interest in transcending black letter law. This article suggests that the reasons for the late conceptualization of cultural expertise lies on the one hand in the difficulty of defining the dynamics between law and culture, and on the other hand in the specific development of legal pluralism regarding the state. The

1. Livia Holden, Cultural Expertise and Litigation. Patterns, Conflicts, Narratives (Abingdon: Routledge, 2011). 
PROOFS: Please cite as Holden, Livia (forthcoming) Cultural Expertise and Law: An Historical Overview, Law and History Review, Cambridge.

undertheorization of the engagement of anthropologists with law is better understood in connection with the axiomatic binary opposition between state law and non-state law. This opposition has had a central role in the theoretical elaborations of legal pluralism since its inception. This article concludes that there is an urgent need to conceptualize and investigate cultural expertise as a field of research to comprehensively assess the contribution of sociocultural knowledge to the resolution of conflicts and governance, and proposes a broader definition of cultural expertise.

\section{From Social Evolutionism to Legal Pluralism}

The systematic study of the relationship between law and culture started in the second half of the nineteenth century, whose dominant paradigm in the social sciences was social evolutionism. The evolutionism that burgeoned in the late nineteenth century argued that there would be common stages of development for humanity as a whole, based on the model of Western countries. Undermined by Franz Boas, social evolutionism experienced a partial revival and readaptations between 1930 and 1960 and later again in the 1970s with Marvin Harris's ecological anthropology. ${ }^{2}$

Against the backdrop of the dominant social evolutionist paradigm, the works of Henry Maine and Lewis Morgan represent two different approaches to law and culture. The former remained firmly anchored with written sources, ${ }^{3}$ whereas the

2. Marvin Harris, Cannibals and Kings. The Origins of Cultures (London: Collins, 1978). Stephen Sanderson, “An Evolutionary Interpretation of Fertility Decline: New Evidence," Population and Environment 22 (2001): 555-63.

3. Raymond Cocks, “Sir Henry Maine: 1822-1888,” Legal Studies 8 (1988): 247-57. 
PROOFS: Please cite as Holden, Livia (forthcoming) Cultural Expertise and Law: An Historical Overview, Law and History Review, Cambridge.

latter engaged with empirical research and social action. Notwithstanding the disparity of their methodologies, Maine and Morgan provided the first theoretical and empirical tools to investigate the relationship between law and culture: comparativism and fieldwork.

Henry Maine, a historian and legal comparativist, maintained that it was possible to understand non-Western societies by comparing their legal features to previous stages of development of Western societies: Roman law, particularly the thinkers of the Antonine Period, was his paradigm. ${ }^{4}$ Relying mainly on written sources and the comparative method, Maine travelled very little and hardly conducted any fieldwork. ${ }^{5}$ In contrast, Morgan developed his knowledge as a result of extensive periods of fieldwork among the Iroquois,${ }^{6}$ and engaged with what I see as antecedents of cultural

4. George A. Feaver, "The Political Attitudes of Sir Henry Maine: Conscience of a 19th Century Conservative 1," The Journal of Politics 27 (1965): 297.

5. Suomyendra N. Mukhejee, "The Idea of the Village Community and the British Administrators," Enquiry, New Series 3 (1971): 66-67.

Baden H. Baden-Powell, The Indian Village Community: Examined with Reference to the Physical, Ethnographic, and Historical Conditions of the Provinces; Chiefly on the Basis of the Revenue-Settlement Records and District Manuals (London: Longmans, Green, 1896), 229.

6. Leslie White, “Lewis H. Morgan's Western Field Trips,” American Anthropologist 53 (1951): 11. 
PROOFS: Please cite as Holden, Livia (forthcoming) Cultural Expertise and Law: An Historical Overview, Law and History Review, Cambridge.

expertise and advocacy by supporting the Seneca in retrieving the land fraudulently obtained by the Ogden Land Company. ${ }^{7}$

Morgan's engagement with the Iroquois went as far as founding the "The New Confederacy of Iroquois" with the purpose of resurrecting the Iroquois spirit by learning the Iroquois language, adopting Iroquois names, and becoming Iroquois by undergoing a ritual called inindianation. ${ }^{8}$ Similar phenomena of "Indian enthusiasm" occurred in Germany in the nineteenth and twentieth centuries and are still alive today as a form of advocacy in favor of minority groups, and are initiated and developed almost exclusively by individuals belonging to majorities. ${ }^{9}$ This kind of top-down advocacy characterized much of early legal pluralism when social scientists were interested in the functioning of law in colonized societies and marvelled at the existence of so-called "indigenous laws."

7. Henry Morgan Lewis, League of the Ho-dé-no-sau-nee, or, Iroquois (Rochester: Rochester \& Co, 1851).

8. William Fenton, "The Iroquois Confederacy in the Twentieth Century: A Case Study of the Theory of Lewis H. Morgan in 'Ancient Society,"” Ethnology 4 (1965): $251-65$.

9. Hartmut Lutz, "German Indian Enthusiasm: A Socially Constructed German National(ist) Myth," in Germans and Indians: Fantasies, Encounters, Projections, ed. Gerd Gemnden Colin, Gordon Calloway, and Susanne Zantop (Lincoln, NE: University of Nebraska Press, 2002), 168.

10. John M. Conley and William M. O'Barr, "A Classic in Spite of Itself: 'The Cheyenne Way' and the Case Method in Legal Anthropology (Book Review)," Law 
PROOFS: Please cite as Holden, Livia (forthcoming) Cultural Expertise and Law: An Historical Overview, Law and History Review, Cambridge.

In the first few decades of the twentieth century, the new paradigm of cultural relativism started to undermine the foundation of the historical comparative approach grounded on unilinear evolutionism. Cultural relativism doubted that so-called primitive groups had laws, and argued that even if they had something similar, they would not be able to articulate them. ${ }^{11}$ When E. Adamson Hoebel set out for his research on the law of the Plain Indians, he contacted, on Boas's advice, the lawyer Karl Llewellyn, who proposed a methodology that would remain widely known as the "case study method." Two other conceptual tools elaborated by Llewellyn were adopted in their collaborative research: the law-job theory and the legal realism approach. The former underlines that the group's survival depends on the satisfactory performance of the system of dispute resolution, ${ }^{12}$ whereas the latter indicates a break from deductive methodology grounded on the law on the books and an opening toward a scientific empirical analysis of the law in action..$^{13}$

\& Social Inquiry 29 (2004): 185; and Kaius Tuori, “The Disputed Roots of Legal Pluralism," Law, Culture and the Humanities 9 (2013): 330-51.

11. William Twining, "Law and Anthropology: A Case Study in Inter-Disciplinary Collaboration," Law and Society Review 7 (1973): 561.

12. William Twining, "Two Works Of Karl Llewellyn," Modern Law Review 30 (1967): 514-30.

13. David Ingersoll, "Karl Llewellyn, American Legal Realism, and Contemporary Legal Behavioralism,” Ethics 76 (1966): 253-66. 
PROOFS: Please cite as Holden, Livia (forthcoming) Cultural Expertise and Law: An Historical Overview, Law and History Review, Cambridge.

Hoebel and Llewellyn's book, The Cheyenne Way, is hailed as the most successful example of collaboration between an anthropologist and a lawyer. ${ }^{14}$ It is also considered to be the first book to lay the theoretical groundwork for the notion of legal pluralism, which would become one of the key concepts in future sociolegal scholarship. ${ }^{15}$ However, recently, cogent criticism was raised against Hoebel and Llewellyn because, despite their efforts to understand Cheyenne law in their own terms, many legal categories that the authors employed came from Western legal vocabulary. ${ }^{16}$

During the first half of the twentieth century, Arthur Shiller and Felix Cohen applied legal pluralism to field research. Shiller indicated as a model of legal pluralism the preservation of the Adat, or customary laws, by the Dutch in Indonesia. Cohen, who was a government lawyer and reputed scholar, defended the human rights of First Nations. ${ }^{17} \mathrm{He}$ is representative of the early scholarship that engaged both academically and administratively in favor of minorities, ${ }^{18}$ and at a time when the

14. Karl N. Llewellyn and Adamson E. Hoebel, The Cheyenne Way. Conflict and Case Law in Primitive Jurisprudence (Norman: University of Oklahoma Press, 1941); and Conley and O’Barr, “A Classic in Spite of Itself,” 214.

15. Daniel Kroslak, "The Idea of Legal Pluralism (with Regard to the Conception of Leopold Pospisil)," SSRN Electronic Journal, 2011. [AU: Either provide volume and page numbers, or URL and date accessed.]

16. Conley and O’Barr, “A Classic in Spite of Itself,” 191.

17. Tuori, "The Disputed Roots of Legal Pluralism."

18. Kevin K. Washburn and Dalia Tsuk Mitchell, "Felix Cohen, Anti-Semitism and American Indian Law,” American Indian Law Review 33 (2008): 583. 
PROOFS: Please cite as Holden, Livia (forthcoming) Cultural Expertise and Law: An Historical Overview, Law and History Review, Cambridge.

engagement in favor of minorities stemmed from within, and despite, the colonial enterprise. ${ }^{19}$

In the 1960 s, the case study method was consolidated in the social sciences, but a new contention was raised by Paul Bohannan and Max Gluckman, which would engross legal anthropology for a long time: indigenous legal terminology versus the Anglo-American equivalent. The Bohannan-Gluckman debate continues on today, sometimes in disguise, to hunt and divide not only legal anthropologists but also sociolinguists, ${ }^{20}$ and is particularly relevant for legal anthropology and cultural expertise: how to translate legal categories without deceiving their original meanings.

Until the mid-twentieth century, the boundaries between anthropology and sociology both in France and in Britain had been permeable, with Emile Durkheim and Marcel Mauss holding important positions in both disciplines. Sociologists and anthropologists alike used to contribute to prevalent sociology journals such as Cahiers internationaux de sociologie and Sociological Review. The distinction between the two disciplines was further blurred when anthropologists set out to study metropolitan communities through an anthropological lens. ${ }^{21}$

Toward the second half of the twentieth century, the emphasis on the development of new emerging nations made sociology a more suitable discipline as a receptacle of funding. Between the 1950s and the 1980s in France, sociology came to be perceived

19. Tuori, “The Disputed Roots of Legal Pluralism.”.

20. John M. Conley, William M. O'Barr, and Robin C. Riner, Just Words: Law, Language, and Power (Chicago: University of Chicago Press, 2019).

21. George Steinmetz, "Sociology and Colonialism in the British and French Empires, 1945-1965,” The Journal of Modern History 89 (2017): 610. 
PROOFS: Please cite as Holden, Livia (forthcoming) Cultural Expertise and Law: An Historical Overview, Law and History Review, Cambridge.

by younger scientists as somewhat avant-garde, especially in contrast with ethnology, leading to a unbalanced distribution of scholars among the various disciplines of social sciences, with a majority favoring sociology. ${ }^{22}$ Sociologists argued that their methods were more appropriate to the study of African societies because as developing countries, these were now subjected to the same dynamics as Europeans societies. ${ }^{23}$ Moreover, local intellectuals in developing countries argued that they deserved to be studied by the type of scientists that studied so-called "civilized societies": the sociologists,${ }^{24}$ whereas new African universities excluded anthropology or relegated it as a subfield of sociology. ${ }^{25}$

In the early 1970 s, the reaction to the crisis of sociological scholarship of the 1950s and 1960s gave rise in Europe and the United States to a radical scholarship influenced by Marxism. ${ }^{26}$ The legal nihilism that characterized Marxist scholarship diverted sociology away from legal studies. ${ }^{27}$ Since the 1980 s, a renewal of interest in

22. Ibid., 611.

23. Ibid., 612.

24. Gwilym I. Jones, "Social Anthropology in Nigeria during the Colonial Period," Africa: Journal of the International African Institute 44 (1974): 280-89.

25. Steinmetz, "Sociology and Colonialism in the British and French Empires, 1945$1965, " 612$.

26. Mathieu Deflem, "The Structural Transformation of Sociology," Society 50 (2013): 156-66.

27. Steven Spitzer, "Marxist Perspectives in the Sociology of Law," Annual Review of Sociology 9 (1983): 103-24. 
PROOFS: Please cite as Holden, Livia (forthcoming) Cultural Expertise and Law: An Historical Overview, Law and History Review, Cambridge.

sociological studies of law led to the foundation of dedicated institutions, ${ }^{28}$ whose methodology and research themes sometimes intersect those of legal anthropology, but tend to focus almost exclusively on industrialized nations with democratic political systems. ${ }^{29}$

In summary, the relationship between law and culture in the early history of legal anthropology was largely overlooked, and this hindered a critical reflection on the use of social science knowledge for dispute resolution. The development of fieldwork methods and the emphasis on case studies facilitated the engagement of some social scientists, who played a role in advocating the rights of minorities, but this was not accompanied by any self-reflective stance on their own role vis-à-vis the state and colonial power. When such a reflection started to develop later on, with a new focus on industrial societies against the backdrop of postcolonial discourse and Marxist ideology, attention to the relationship between law and culture was sidelined in favor of a state-centered approach to law that often deemphasized minorities' and subalterns' rights.

\section{The New Legal Pluralism, and Power and Justice Debates}

28. Javier A. Treviño, "The Sociology of Law in Global Perspective," The American Sociologist 32 (2001): 5-9.

29. Reza Banakar, "The Sociology of Law: From Industrialisation to Globalisation" Sociopedia.isa, University of Westminster, School of Law Research Paper 11-03 (2011) [AU: Please provide page numbers.]. 
PROOFS: Please cite as Holden, Livia (forthcoming) Cultural Expertise and Law: An Historical Overview, Law and History Review, Cambridge.

The first legal pluralism, which valued so-called "customary law," without critically challenging the impact of colonial power, was partially redeemed by the new legal pluralism. In the 1960s, Leopold Pospisil criticized legal comparatists for drawing on components of law that were similar to Western counterparts, even as they dignified the law of so-called primitive societies. For Pospisil, this approach obviated a more comprehensive understanding of non-Western law, which, he argued, should instead be understood in relation to non-Western culture. ${ }^{30}$ Pospisil's legal pluralism diverted from the colonial origins of the concept by introducing a more widespread notion of plurality, which would be inherent to all societies at different legal levels. ${ }^{31}$ According to Pospisil, all the different subgroups of society-including families, lineages, and political parties_-feature their own legal systems. ${ }^{32}$ This approach remains innovative today, especially in light of the recent reinforcement of statecentered approaches to law.

In "Legally Induced Culture Change in New Guinea," Pospisil reveals that Dutch colonial administrators used his own works on Kapaku law for their determinations of customary law. ${ }^{33}$ This underlines the role and involvement of social scientists in recording and interpreting customary law, but also suggests a critical

30. Leopold Pospisil, "Legal Levels and Multiplicity of Legal Systems in Human Societies," The Journal of Conflict Resolution 11 (1967): 2-26.

31. Ibid.

32. Ibid.

33. Leopold Pospisil, "Legally Induced Culture Change in New Guinea," in The Imposition of Law, ed. Sandra Burman and Barbara Harrell-Bond (New York: Academic Press 1979), 127-44. 
PROOFS: Please cite as Holden, Livia (forthcoming) Cultural Expertise and Law: An Historical Overview, Law and History Review, Cambridge.

reflection anticipating the now-emergent concept of lawfare, which is today defined as social change engineered by legal reforms used as political tools. ${ }^{34}$ In the 1970 s, Pospisil pushed classical legal pluralism toward the new legal pluralism, and was among the first to engage with criticism against colonialism. ${ }^{35}$ Although classical legal pluralism generated from the discovery that colonial law coexisted with socalled indigenous law, Pospisil and others criticized the colonial definition of customary law or indigenous law because it romanticized a stereotypical perspective of primitive law. ${ }^{36}$ The new legal pluralism also offered a new conceptualized plurality of law to denounce the power imbalance between less-developed societies of the world's global South and industrial societies in Europe and the United States.

Brian Z. Tamanaha later criticized the new legal pluralism scholars arguing that their approach was embraced by social scientists for opportunistic motives. $\mathrm{He}$ also maintained that customary law was nothing else than a creation of the legal pluralism approach. ${ }^{37}$ His criticism undermined the political and historical background of the new legal pluralism, which resonated with the discussions of the

34. Charles Dunlap, "Lawfare 101. A Primer," Military Review [AU: Please provide volume number if there is one.](May-June 2017): 8-17.

35. Pospisil, "Legally Induced Culture Change in New Guinea," 127-44.

36. On the criticism of romanticized view of indigenous law, see Peter Fitzpatrick, Law and State in Papua New Guinea (London: Academic Press 1980); and June Starr and Jane Fishburne Collier, History and Power in the Study of Law: New Directions in Legal Anthropology (Ithaca: Cornell University Press 1989).

37. Brian Z. Tamanaha, "The Folly of the 'Social Scientific' Concept of Legal Pluralism," Journal of Law and Society 20 (1993): 204-5. 
PROOFS: Please cite as Holden, Livia (forthcoming) Cultural Expertise and Law: An Historical Overview, Law and History Review, Cambridge.

1960s and 1970s about power and justice, as in the notorious debate between Michel Foucault and Noam Chomsky. ${ }^{38}$ Foucault denounced the pervasiveness of abuses perpetrated within state institutions, which were supposed to act for the well-being of citizens, whereas Chomsky proposed a model in which smaller subgroups would govern themselves. Both Foucault and Chomsky criticized the abusive power of legal systems as faceless and as unaccountable mechanisms that are supposed to provide justice. Both suggested that justice could also be pursued outside state institutions, inexplicitly rejoining the notions of legal pluralism that would see the presence of a legal system in all subgroups of society. ${ }^{39}$

Pospisil's conceptualization of law as loosely linked with the state would have perhaps been the first opportunity in the history of legal anthropology to theorize cultural expertise. However, in the late twentieth and early twenty-first century, the sociolegal scholarship fractioned into three main positions: state-centered legal pluralism, deep pluralism, and global legal pluralism.

State-centered legal pluralism asserts the hegemony of state law over other concurrent legal systems and focuses on the interconnection between state law and other normative systems within the state. ${ }^{40}$ It situates the locus of power in the state, which has the ultimate say. Early iterations of legal anthropology avoided a direct confrontation with state law because it focused on small groups, because of their

38. Noam Chomsky and Charles Foucault, “Justice versus Power" https://www.youtube.com/watch?v=J5wuB_p63YM (November 23, 2018).

39. Noam Chomsky and Barry Pateman, Chomsky on Anarchism (Edinburgh; Oakland, CA: AK Press, 2005), 173.

40. Tuori, "The Disputed Roots of Legal Pluralism.” 
PROOFS: Please cite as Holden, Livia (forthcoming) Cultural Expertise and Law: An Historical Overview, Law and History Review, Cambridge.

supposedly unadulterated customs. However, even champions of minority rights such as Felix Cohen, while advocating for the rights of Indian Americans, left little margin for consulting them on legal provisions and policies concerning their rights. ${ }^{41}$ Tamanaha's criticism of this early brand of legal pluralism that aimed to rebalance the status of non-state laws vis-à-vis state laws, is based on the failure of legal anthropology to define law outside the state law framework. ${ }^{42}$ Similarly, Ralf Michales contends that the state remains the ultimate arbiter of law. Non-state legal pluralism fails to appreciate that the state, while dealing with non-state normative orders, may acknowledge their existence and find them a niche, without, however, recognizing them as binding law. ${ }^{43}$ Joan Cohen identifies the factual incommensurability of state and non-state law even more strongly. For Cohen, any bargain between state and non-state laws, in particular religious law, is doomed to fail. Cohen also asserts that the acknowledgment of normative orders other than state law should rely on individual claims. ${ }^{44}$

Yet, since the 1980 s a number of scholars have extended the non-state legal pluralism approach and attempted to overcome the binary opposition between state

41. Ibid.

42. Tamanaha, "The Folly of the 'Social Scientific' Concept of Legal Pluralism," $192-217$.

43. Ralf Michaels, "The Re-State-Ment of Non-State Law: The State, Choice of Law, and the Challenge from Global Legal Pluralism," Wayne Law Review 51 (2005): $1209-59$.

44. Jean L. Cohen, "The Politics and Risks of the New Legal Pluralism in the Domain of Intimacy,” International Journal of Constitutional Law 10 (2012): 380-97. 
PROOFS: Please cite as Holden, Livia (forthcoming) Cultural Expertise and Law: An Historical Overview, Law and History Review, Cambridge.

and non-state law. Sally Engle Merry’s seminal article "Legal Pluralism," 45 offers an alternative to state-centered legal pluralism. Merry refuses to accept the legal hegemony of state law, reframes normative orders into their social and historical contexts, analyzes the relationship between law as a system of thoughts and power, and broadens the scope of legal pluralism to include social components of law. ${ }^{46}$ Legal anthropologists have also developed deep legal pluralism or non-state legal pluralism, which focuses on small communities and their problem-solving methods. It assumes an emancipatory agenda, which is often overlooked because colonial administrators commissioned early deep legal pluralism studies. ${ }^{47}$ Kaius Tuori's work is an example of this challenge to the purported hegemony of the state law example. Tuori illustrated the passage from a situation of state legal pluralism to one of deep legal pluralism in post-apartheid South Africa. Deep legal pluralism maintains that the paradigm of state legal pluralism is inapplicable to alternative normative cultures that exist independently and autonomously from the state legal system. ${ }^{48}$

The most recent proponents of non-state legal pluralism counter the claim that state law retains a privileged role, by disputing its legitimacy and by reconfiguring the loci of law. Santos de Souza displaces and diffuses normative orders in six sociogeographical places_-household-place, work-place, market-place, communityplace, citizen-place, and world-place - that cohere because of the specific form of

45. Sally Engle Merry, “Legal Pluralism,” Law and Society Review 22 (1988): 874.

46. Ibid.

47. Tuori, "The Disputed Roots of Legal Pluralism,” 337.

48. Ibid. 
PROOFS: Please cite as Holden, Livia (forthcoming) Cultural Expertise and Law: An Historical Overview, Law and History Review, Cambridge.

social relations that are being developed within them. ${ }^{49}$ Furthermore, he bypasses the problem of strictly defining law by extending it to all normative orders, including, but not limited to, state law, and holding three characteristics: rhetoric, violence, and bureaucracy. Nonetheless, Emmanuel Melissaris takes to task de Souza and his interlocutors because their non-state legal pluralism has not yet fulfilled its heuristic and pragmatic potential, and suggests a more radical shift from positivism and classical legal anthropology to emphasize the sociocultural dimensions of law. ${ }^{50}$

Global legal pluralism, which aims to eliminate the reliance on territorybounded legal systems and offers a more fluid approach capable of describing transnational and transcultural conflicts, is a third emerging trend. ${ }^{51}$ It emerged in the 1990s as a re-evaluation of the first wave of legal pluralism scholarship. But global legal pluralism broke new ground by emphasizing localized settings. Whereas many among the proponents of legal pluralism were concerned by the rise of liberal legality, which they saw as an instrument for asserting economic dominance, the representatives of global legal pluralism have abandoned much of the radical criticism against liberal legality. Law professors and legal philosophers dominate the ranks of global legal pluralists, whereas sociologists and anthropologists tend to be the

49. Boaventura De Sousa Santos, Toward a New Common Sense: Law, Science and Politics in the Paradigmatic Transition (London: Routledge, 1995).

50. Emmanuel Melissaris, "The More the Merrier? A New Take on Legal Pluralism," Social \& Legal Studies 13 (2004): 76.

51. Paul Schiff Berman, "Global Legal Pluralism and 'Private' International Law," Transnational Legal Theory 1 (2010): 117-20. 
PROOFS: Please cite as Holden, Livia (forthcoming) Cultural Expertise and Law: An Historical Overview, Law and History Review, Cambridge.

majority among non-state legal pluralists. ${ }^{52}$ Global legal pluralism posits that there is more than one normative order. and appreciates that non-state entities often brandish more power than state law. It avoids the issue of legal legitimacy, but focuses on how legal or quasilegal norms are perceived by social actors and how their perceptions affect power dynamics in negotiating legal spaces. ${ }^{53}$

In sum, existing trends of legal pluralism, including also state-centered legal pluralism, should all be conducive to a reflection about cultural expertise, because the mere acknowledgement of a plurality of laws calls for a knowledge that exceeds the law on the books and highlights the links between law and culture. However, the very link between law and culture has been a source of preoccupation for legal pluralism scholarship. In particular, debates have revolved around the risk that cultural accommodation of minorities, as argued by legal pluralism, might in fact become or perpetuate discrimination against the very groups that it intends to recognize and protect.

\section{Legal Pluralism as Cultural Accommodation or a Source of Discrimination}

The increasing demand for cultural accommodation in the first few decades of the twenty-first century has led to a significant development of legal pluralism. Roger Ballard, Werner Menski, and Prakash Shah have all argued that European countries must include non-European minorities and their laws within the current European

52. Paul Schiff Berman, "The Evolution of Global Legal Pluralism," SSRN Electronic Journal [AU: Please provide volume number.] (2016): 151-88.

53. Ibid. 
PROOFS: Please cite as Holden, Livia (forthcoming) Cultural Expertise and Law: An Historical Overview, Law and History Review, Cambridge.

legal systems. ${ }^{54}$ Shah denounces the notion that indigenous legal traditions both in Western and non-Western countries suffer from a hierarchical imbalance because of the hegemony of Euro-American legal systems. Therefore, legal practices that originated in Asian countries are confined to an ethnic niche that never finds adequate recognition. ${ }^{55}$ Shah, Marie-Claire Foblets, and Mathias Rohe attest to the fact that religious laws in concomitance with European secular state law allow for the resolution of family law disputes at religious jurisdictions established among minority groups. ${ }^{56}$ Nevertheless, their findings have led thus far to neither a formal recognition of the multiple sources of law within and outside the state, nor a theorization of the expertise needed to deal with legal pluralism in conflict settlement. Among the objections formulated against the legal accommodation of plural societies, that which

54. Roger Ballard, "When, Why and How Far should Legal Systems take Cognisance of Cultural Diversity?" International Congress on Justice and Human Values in Europe (Karlsruhe, 2007). [AU: Should this have a publisher? Or is it a paper presented at this Congress?] Werner Menski, "Life and Law: Advocacy and Expert Witnessing in the UK," in Cultural Expertise and Litigation: Patterns, Conflicts, Narratives, ed. Livia Holden (London: Routledge 2011), 151-71; and Prakash Shah, Law and Ethnic Plurality: Socio-Legal Perspectives, Immigration and Asylum Law and Policy in Europe (Leiden: Martinus Nijhoff Publishers, 2007).

55. Prakash Shah, Legal Pluralism in Conflict: Coping with Cultural Diversity in Law (London: Glasshouse Press, 2016), 59.

56. Prakash Shah, Marie-Claire Foblets, and Mathias Rohe, Family, Religion and Law: Cultural Encounters in Europe, Cultural Diversity and Law (Farnham: Ashgate, 2014). 
PROOFS: Please cite as Holden, Livia (forthcoming) Cultural Expertise and Law: An Historical Overview, Law and History Review, Cambridge.

most deserves attention, in my view, is the danger that non-state law may perpetuate the power imbalance suffered by minorities.

Some theoretically inclined legal pluralists caution against the unreserved support of non-state jurisdictions that are embedded in unequal and patriarchal social settings. Archana Parashar has criticized the supporters of personal laws in India for the lack of social responsibility that they afford to the cause of women's rights. ${ }^{57}$ Samia Bano has disclosed women's perspectives on religious tribunals in the United Kingdom in order to point out that non-state jurisdictions, while upholding the values of minority groups, can also perpetuate the vulnerability of those who are minorities within minorities. ${ }^{58}$ Overall, feminist and Marxist scholarships have remained skeptical about the opportunity to accommodate non-Western laws and customs, because doing so will be detrimental to the rights of vulnerable sectors of minority groups. ${ }^{59}$ Thus, by opposing categorically the appreciation of non-state law, they have substantially rejoined the most conservative approaches that deny accommodation to

57. Archana Parashar, "Religious Personal Laws as Non- State Laws: Implications for Gender Justice,” The Journal of Legal Pluralism and Unofficial Law 45 (2013): 5-23. 58. Samia Bano, Gender and Justice in Family Law Disputes: Women, Mediation, and Religious Arbitration (Waltham, MA: Brandeis University Press, 2017).

59. Susan Moller Okin, Joshua Cohen, Matthew Howard, and Martha Craven Nussbaum, Is Multiculturalism Bad for Women? (Chichester: Princeton University Press, 1999); Sawitri Saharso and Baukje Prins, "In The Spotlight: A Blessing and a Curse for Immigrant Women in the Netherlands," Ethnicities 8 (2008): 366-84; Archana Parashar, "Religious Personal Laws as Non- State Laws: Implications for Gender Justice.” 
PROOFS: Please cite as Holden, Livia (forthcoming) Cultural Expertise and Law: An Historical Overview, Law and History Review, Cambridge.

minorities. Hence, the contention that legal pluralism might perpetuate discrimination and that state-centered law only would ensure equality remains unconvincing.

Other subscribers to legal pluralism have been attentive to social inequalities by adopting power as an analytical variable and arguing for social reforms. Melissaris, for example, refutes the hegemony of state legal pluralism and interprets resistance through persistent traditional law practices. He argues that legal pluralism should be more of a forum that allows a multiplicity of theories and legal discourses to communicate and creatively interact. ${ }^{60}$ In my work, I show that the customary practices recognized by personal Hindu law embody the dichotomy of the plurality of legal sources in India: on the one hand as potentially supporting women's initiative in matrimonial remedies, and on the other, as potentially being an instrument for the perpetuation of gender inequalities. ${ }^{61} \mathrm{I}$ argue that it is possible to overcome the limitations of classical legal pluralism and the polarization of the new legal pluralism without missing out on their innovations. My findings in South Asia show that state law as much as non-state law, has the potential to be serviceable to objectionable endeavors and discriminatory political agencies. However, sometimes specific interpretations of state and non-state law can be of help to minorities. It might help, therefore, to again shift the focus of the analysis from the ontology of law to its practices, and perhaps re-evaluate Pospisil's notion of plurality beyond the opposition of state law and non-state law, for highlighting the dynamic linkages between law and culture.

60. Melissaris, "The More the Merrier? A New Take on Legal Pluralism,” 62. 61. Livia Holden, Hindu Divorce. A Legal Anthropology (Aldershot: Ashgate, 2008). 
PROOFS: Please cite as Holden, Livia (forthcoming) Cultural Expertise and Law: An Historical Overview, Law and History Review, Cambridge.

Some studies have shown, for example, that within the professional sector of state law, lawyers, embassies, translators, nongovernmental organizations, and private offices do provide legal aid and lobby for legal change to protect the rights of minorities in Europe. ${ }^{62}$ At times, members of the most influential minority communities can tap into this field for expertise and assistance on family and migration law issues, and are assisted in negotiations between European laws and the legal system in their country of origin. However, less influential minorities usually lack adequate support. ${ }^{63}$

However, most recent legal pluralist scholarship argues that multicultural accommodation should also include social reforms that account for intercommunity relations and new systems of governance that redress traditional vulnerabilities. In particular, the concept of transformative accommodation and prescriptive legal pluralism developed by Ayelet Shachar resonates well among sociolegal scholars because it offers a potential solution to the integration of communities branded as inequitable. ${ }^{64}$ Ralph Grillo suggests that a compromise should be reached between

62. Veronique Bouillier, "French Law Courts and South Asian Litigants," in Cultural Expertise and Litigation: Patterns, Conflicts, Narratives, ed. Livia Holden (London: Routledge, 2011), 53-70; Tommaso Sbriccoli and Stefano Jacoviello, "The Case of S: Elaborating the 'Right' Narrative to Fit Normative/Political Expectations in Asylum Procedure in Italy," in Cultural Expertise and Litigation, 172-94.

63. Iris Sportel, 'Maybe I'm Still his Wife.' Transnational Divorce in Dutch-Moroccan and Dutch-Egyptian Families (Nijmegen: Radboud University, 2014).

64. Ayelet Shachar, Multicultural Jurisdictions: Cultural Differences and Women's Rights (Cambridge: Cambridge University Press, 2001). 
PROOFS: Please cite as Holden, Livia (forthcoming) Cultural Expertise and Law: An Historical Overview, Law and History Review, Cambridge.

the state and minorities that will allow the former to integrate minorities into mainstream society, while benefitting the latter with a certain degree of autonomy on matters that are deemed essential for their group identity. ${ }^{65}$

Sachar's prescriptive legal pluralism has been criticized for inducing the state, whose responsibility is to ensure gender equality, into a power bargain with orthodox religious groups, whose patriarchy and misogyny will only be rewarded after state recognition. Cohen, while admitting the descriptive value of the legal pluralism concept as "a multiplicity of normative orders coexisting in a social space," shows the pitfalls of its application in the concept of transformative accommodation. ${ }^{66}$ According to Cohen, effective transformative accommodation ensuring gender equality, can and should be controlled by the state through incentives and by focusing on individuals instead of on groups. ${ }^{67}$ In sum, both Cohen and Shachar share the assumption that state law and non-state law are necessarily opposed, and pursue diverging targets.

Although the contemporary de facto plurality generated de facto arrays of instruments that fall under the umbrella concept of cultural expertise and thereby transcend the binary opposition between state and non-state law, ${ }^{68}$ the latter remains central to classical legal pluralism. It relegates culture to a component of non-state

${ }^{65}$ Ralph D. Grillo, Legal Practice and Cultural Diversity (London: Routledge, 2016). 66. Cohen, "The Politics and Risks of the New Legal Pluralism in the Domain of Intimacy," 387-88.

67. Ibid., 393-97.

68. Livia Holden, ed., Cultural Expertise and Socio-Legal Studies (Bingley, UK: Emerald Publishing, 2019). 
PROOFS: Please cite as Holden, Livia (forthcoming) Cultural Expertise and Law: An Historical Overview, Law and History Review, Cambridge.

law that tendentially supports discrimination against minorities, and perpetuates the power imbalance against minorities within minorities. In such a framework, cultural expertise tends to play an informal and peripheral role in conflict resolution and therefore escapes theorization. Yet contemporary debates on law and culture offer a new dimension that might open up to a more articulated consideration of the practices that I propose to see as cultural expertise.

\section{Contemporary Debates on Law and Culture}

Even though most sociolegal scholarship assumes the usefulness of accommodating multiple sources of law, which emphasize the connection between law and culture, it nonetheless retains a dichotomy between black letter law, as potentially ensuring equality, and law in action, as potentially fostering diversity but undermining human rights. Franz and Keebet Benda-Beckman have mobilized the notion of the plurality of laws approved by the state, ${ }^{69}$ whereas Marie-Claire Foblets and Alison Dundes Renteln advocate for the development of policy making in favor of under-represented groups within minorities, ${ }^{70}$ perhaps in order to overcome the growing criticism against legal pluralism. Notably, the Benda-Beckmans have expanded the notion of

69. Franz Benda-Beckmann and Keebet Benda-Beckmann, "The Dynamics of Change and Continuity in Plural Legal Orders," Journal of Legal Pluralism and Unofficial Law 38 (2006): 1-44.

70. Ibid.; and Marie-Claire Foblets and Alison Dundes Renteln, Multicultural Jurisprudence: Comparative Perspectives on the Cultural Defense (Portland, OR: Hart Publishing, 2009). 
PROOFS: Please cite as Holden, Livia (forthcoming) Cultural Expertise and Law: An Historical Overview, Law and History Review, Cambridge.

legal pluralism to become an operational tool, and thus emphasize the power of the descriptive analytical role of the concept. ${ }^{71}$ If, however, scholars address legal pluralism from the point of view of the attainment of social justice, they should embrace empirical analysis, especially in the implementation of international human rights and long-term economic transformations in favor of the unprivileged. As a consequence, they must also investigate the role of social scientists in collecting, elaborating, and disseminating data, because these practices ultimately influence the perception of law and its relationship with justice.

How are data accessed? And what data can be considered to be reliable in order to measure social justice? Because of the difficulty in finding a satisfactory answer to these questions, some sociolegal scholarship has scrutinized the very capacity of the law to address global inequalities, and has become disenchanted with the world of global and inclusive citizenship. Criticism is now focused on the ideology of global commensurability, in which the world would be revealed through different kinds of numerical representation. Renè Urueña, in "Indicators and the Law: A Case Study of the Rule of Law Index," questions the reliability of the indicators of the rule of law, because their ostensible simplicity and neutrality make them rife for political manipulation. ${ }^{72}$ Mihaela Serban explains how the selective mobilization of

71. Benda-Beckmann and Benda-Beckmann, "The Dynamics of Change and Continuity in Plural Legal Orders.”

72. Renè Urueña, "Indicators and the Law: A Case Study of the Rule of Law Index," in The Quiet Power of Indicators: Measuring Governance, Corruption, and Rule of Law, ed. Sally Engle Merry, Kevin E. Davis, and Benedict Kingsbury (Cambridge: Cambridge University Press 2015), 75-102. 
PROOFS: Please cite as Holden, Livia (forthcoming) Cultural Expertise and Law: An Historical Overview, Law and History Review, Cambridge.

the indicators of the rule of law serves the interests of their users, both state and nonstate actors. Serban emphasizes that their interpretation is "highly context motivated" insofar as defeating the very reasons, neutrality, and impartiality, of their production. ${ }^{73}$ Sally Engle Merry, Kevin E. Davis, and Benedict Kingsbury have shown that the overvaluation of indicators in international law has brought about a conundrum in which it is the very action of measurement that makes a phenomenon apparent and existing. Yet whatever cannot be measured does not exist. ${ }^{74}$ It could be inferred that from this quantitative perspective that the link between law and culture is deemed to be underscored by more measurable social phenomena. In other words, the relationship between law and culture might not only be useless, but, quite paradoxically, might not exist at all.

However, a third way beyond quantitative and qualitative perspectives should also be possible, in order to account for the plurality of sources of law and the close relationship between law and culture. I contend that precisely in this landscape of the global rule of law, in which measurable phenomena are deemed to be more real than other less measurable ones, there is an interest in overcoming the polarization between state law and non-state law of the early days of legal pluralism. ${ }^{75}$ Legal anthropologists have never directly challenged this binary opposition, which is perpetuated by the theoretical approaches of state legal pluralism versus non-state

73. Mihaela Serban, "Rule of Law Indicators as a Technology of Power in Romania," in The Quiet Power of Indicators, 199-221.

74. Merry, Davis, and Kingsbury, The Quiet Power of Indicators.

75. Livia Holden, Legal Pluralism and Governance in South Asia and Diasporas (Abingdon: Routledge, 2014). 
PROOFS: Please cite as Holden, Livia (forthcoming) Cultural Expertise and Law: An Historical Overview, Law and History Review, Cambridge.

legal pluralism. Instead, I suggest, state law and non-state law, even if coming from different sources, very often act as a continuum and eventually achieve what Foucault called in critical terms "governamentality": the art of governments to produce citizens that follow practices to implement their policies. ${ }^{76}$ This approach allows the miscommunication, which stems from the asymmetrical discussions among social groups that suffer from social inequalities yet have developed legal awareness, to be addressed. Such legal awareness neither necessarily refers to the state, nor is it ipso facto against the state, unless this is antagonized, usually by the state. ${ }^{77}$ Hence, a shift toward governance and governamentality dissolves the polarization between state law and non-state law. ${ }^{78}$ However, this is only possible, as Melissaris argues, if we collapse observation into participation in order to allow dispersed legal discourses and theories to become visible at last. ${ }^{79}$ Looking at state law and non-state law as a potential continuum instead of a binary opposition resonates with Gunther Teubner,

76. Michel Foucault, Michel Senellart, and Graham Burchell, The Birth of Biopolitics: Lectures at the Collège de France, 1978-79 (Houndmills, UK: Palgrave Macmillan, 2008).

77. Livia Holden, "Review of Navajo Nation Peacemaking: Living Traditional Justice," PoLAR: Political and Legal Anthropology Review 30 (2007): 352-57; and Boaventura de Sousa Santos, Another Knowledge is Possible; Beyond Northern Epistemologies (London: Verso, 2008).

78. Holden, Legal Pluralism and Governance in South Asia and Diasporas.

79. Melissaris, "The More the Merrier? A New Take on Legal Pluralism," 57-79. 
PROOFS: Please cite as Holden, Livia (forthcoming) Cultural Expertise and Law: An Historical Overview, Law and History Review, Cambridge.

Robert Cover, and Boaventura de Sousa Santos's conceptualization of interlegalities as an interpenetration of different normative orders. ${ }^{80}$

Tuebner's concept of mutual constitution is of particular relevance for cultural expertise in confrontations between state and non-state law. ${ }^{81}$ If, on the one hand, "mutual constitution" admits the impossibility of adequately translating the sociolegal framework of the former into the latter and vice versa, then, on the other hand, through a process of internal adjustment, it opens up to the possibility of internally reconstituting the legal meaning. Cultural expertise provides the instruments to oversee the process of reconstitution of the legal meaning and, by reducing the selectivity of the internal constraints of both state and non-state normative systems, the loss of communication can be prevented. Equally relevant is the concept of dispersed normativities in relation to cultural expertise, as it theoretically accounts for how sociocultural elements affect different normative orders and different orders of normativity. ${ }^{82}$ Hence, the concept of cultural expertise should be able to further develop to enable understanding of how diverse normative orders, which cannot be reduced to state law even from a broad perspective, can be accessed and understood empirically in their everyday connection with culture.

80. Boaventura de Sousa Santos, Toward a New Legal Common Sense: Law, Globalization, and Emancipation (London: Butterworths, 2002): 437; Gunther Teubner, "Substantive and Reflexive Elements in Modern Law," Law and Society Review 17 (1983): 1443-62; and Robert Cover, "Nomos and Narrative," Anamorphosis 2-2 (2017): 187-268.

81. Teubner, "Substantive and Reflexive Elements in Modern Law."

82. Melissaris, "The More the Merrier? A New Take on Legal Pluralism,” 72. 
PROOFS: Please cite as Holden, Livia (forthcoming) Cultural Expertise and Law: An Historical Overview, Law and History Review, Cambridge.

\section{Toward a Reformulation of Cultural Expertise}

Although anthropologists' engagement with law is not new, the development of the concept of cultural expertise has been hindered by the fact that sociolegal studies on state-centered approaches have informed the way social sciences have apprehended the law.

Social scientists and especially anthropologists have been involved with law, lawmaking, policy making and the implementation thereof, dispute resolution, and governance since the times of Lewis Morgan. However, anthropologists' engagement with law has seen a constant struggle between the theorization of diversity on the one hand and the yearning for advocacy in favor of vulnerable groups on the other. These two components should have gone hand in hand, yet this has not always been the case. As a result, anthropology's sister discipline, sociology, has been perceived at times to be less compromised than anthropology vis-à-vis colonial power.

Legal pluralism is perhaps the theoretical approach that could have best defined the engagement of anthropologists with law, because of its valorization of culture and customary laws. Yet the difficulty of theoretically positioning customary law, and subsequent theoretical ramifications, has proven to be a persistent obstacle. This has in turn progressively crystallized the binary opposition between state law and non-state law, and has marginalized considerations of the relationship between law and culture. Similarly, the dominance of quantitive methods has led to the overvaluation of indicators of impact that are susceptible to political manipulation. State-centered legal pluralism and conventional quantitative methods do not allow for 
PROOFS: Please cite as Holden, Livia (forthcoming) Cultural Expertise and Law: An Historical Overview, Law and History Review, Cambridge.

contextualization, and give little room for the theorization of cultural expertise, because they stress the link between law and the state, instead of between law and culture.

The most recent trends of radical legal pluralism, which elude the legitimacy contest between state law and non-state law, appear more fertile to a systematic reflection on the notion of cultural expertise. It is worthwhile to redefine cultural expertise as the special knowledge that enables sociolegal scholars, experts in laws and cultures, or, more generally speaking, cultural mediators - the so-called cultural brokers - to locate and describe relevant facts in light of the particular background of the claimants and litigants and for the decision-making authorities. This reformulation overcomes the Eurocentric limitations of the first definition of cultural expertise, and opens up to out-of-court dispute resolution, but keeps focused on its procedural neutrality. Procedural neutrality, which is not to be confused as neutrality tout court, allows for a differentiation from the concept of cultural defense, in which cultural expertise is used for the purpose of the defense. In that sense, cultural expertise proposes itself as an umbrella concept for all the sociolegal instruments, including cultural defense, which use cultural arguments in court and out of court and hold a variety of roles in the process of dispute resolution. The greatest advantage of conceptualizing cultural expertise is, in fact, not the limitation of its scope, but rather the opportunity to engage in scrutiny of its use, in order to strengthen the ethical engagement of sociolegal scientists in a perspective of societal problem solving. 